\title{
PEMODELAN HIDRODINAMIKA DAN TRANSPOR SEDIMEN DI PERAIRAN PESISIR SEKITAR TANJUNG PONTANG, KABUPATEN SERANG - BANTEN
}

\section{HYDRODYNAMICS AND SEDIMENT TRANSPORT MODELLING AROUND TANJUNG PONTANG COASTAL WATERS, DISTRICT OF SERANG - BANTEN}

\author{
Joko Prihantono ${ }^{1}$, Irfan Arif Fajrianto ${ }^{2}$ dan Yessi Nirwana Kurniadi²
}
'Pusat Riset Kelautan, Badan Riset dan Sumberdaya Manusia, Kementerian Kelautan dan Perikanan ${ }^{2}$ Teknik Sipil Institut Teknologi Nasional-Bandung, Jl. PHH Mustopa No 23 Bandung e-mail : prihantono@gmail.com

\begin{abstract}
ABSTRAK
Tanjung Pontang yang terletak di Provinsi Banten mengalami abrasi pantai dan kekeruhan yang cukup serius. Penelitian abrasi pantai ini telah dibuktikan oleh peneliti lain berdasarkan analisis perubahan garis pantai menggunakan citra satelit dengan tahun yang berbeda, namun penelitian dengan menggunakan pemodelan transpor sedimen belum pernah dilakukan di daerah tersebut. Pemodelan numerik hidrodinamika dan transpor sedimen menggunakan perangkat lunak MIKE21 telah berhasil dilakukan pada penelitian ini untuk membuktikan proses abrasi dan kekeruhan di sekitar Tanjung Pontang. Hasil pemodelan hidrodinamika dengan pembangkit parameter angin menunjukkan adanya arus sejajar garis pantai pada saat musim barat dan musim timur. Pada saat musim barat arus sejajar pantai di Tanjung Pontang dominan bergerak ke arah timur, sedangkan pada saat musim timur sebagian arus sejajar pantai di Tanjung Pontang bergerak ke arah timur, dan sebagian bergerak ke selatan menuju Teluk Banten. Selain itu analisis perubahan bed level menunjukkan adanya penurunan bed level yang mengindikasikan abrasi di sekitar Tanjung Pontang dan adanya sedimentasi di Sungai Ciujung Baru. Kekeruhan terjadi di sekitar Tanjung Pontang dan Teluk Banten disebabkan oleh karena adanya tingginya sedimen tersuspensi di Sungai Ciujung Lama dan terbawa oleh arus sejajar garis pantai di sekitar Tanjung Pontang.
\end{abstract}

Kata kunci: Hidrodinamika, transpor sedimen, Tanjung Pontang, Kabupaten Serang, abrasi.

\section{ABSTRACT}

Pontang Cape is located in Banten Province was suffered from serious abrasion and high turbidity. Abrasion study of Pontang Cape has been proven by another researcher based on coast line changes analysis using satellite imagery in different years, but studies using numerical model in sediment transport have not been done yet in this area. Hydrodynamic and sediment transport numerical modeling using MIKE21 software has successfully done. The result from hydrodynamic model using wind as current generator shows longshore current around Pontang Cape during monsoons. In the west monsoon, the longshore current are predominantly moving eastward, while during the east monsoon some of longshore current move eastward, and some of its move to south toward the Banten Coastal Bay. In addition, a decrease in bed level indicating abrasion around Pontang Cape and sedimentation in the New Ciujung River. The sediment transport modeling shows that turbidity around Pontang Cape and Banten Coastal Bay is caused by the high suspended sediment in the Old Ciujung River, then carried by the longshore currents.

Keywords: Hydrodynamic, Sediment transport, Tanjung Pontang, District of Serang, Abrasion. 


\section{PENDAHULUAN}

Masalah-masalah yang berkaitan dengan transpor sedimen di wilayah pantai dan pesisir adalah sedimentasi, abrasi, dan tingkat kekeruhan air yang tinggi. Sedimentasi dan abrasi dapat terjadi karena dipengaruhi pasang surut air laut dan gelombang. Pada saat terjadi pasang akan terbawa material yang mengendap, sedangkan pada saat surut material akan terkikis (Qomariyah \& Yuwono, 2016). Abrasi menyebabkan perubahan garis pantai yang dapat terjadi akibat adanya pergerakan sedimen karena arus sejajar pantai yang dibangkitkan gelombang (Umar, 2011; Yudhicara \& Yosi, 2011; Angkotasan et al., 2012; Supiyati et al., 2013; Oktiarini et al., 2015; Wisha et al., 2017). Selain itu Aktivitas penambangan pasir juga diduga berdampak terhadap terjadinya abrasi dan kekeruhan air di suatu wilayah. Penambangan pasir yang berlebihan akan mengakibatkan perubahan batimetri (Husrin \& Prihantono, 2014; Husrin et al., 2014; Rahmawan et al., 2017) sehingga akan mempengaruhi perubahan pola hidrodinamika dan transpor sedimen di wilayah tersebut (Kusumawati, 2008; Rachmat \& Purwanto, 2011).

Pesisir utara Kabupaten Serang, Provinsi Banten merupakan wilayah pesisir yang mempunyai permasalahan abrasi yang cukup serius tepatnya di daerah Tanjung Pontang. Hasil penelitian menggunakan penginderaan jarak jauh menunjukkan bahwa telah terjadi perubahan garis pantai di Kecamatan Tirtayasa yang cukup signifikan (Kusumawati, 2008, Husrin \& Prihantono, 2014, P3SDLP, 2014). Penelitian pada tahun 1995-2001 menunjukkan rata-rata erosi di Tanjung Pontang telah menghilangkan lebar pantai hingga $3 \mathrm{~km}$ dan menyebabkan kekeruhan yang tinggi di Teluk Banten (Hoekstra et al., 2003; Hoitink \& Hoekstra, 2003).

Meskipun penelitian abrasi dan kekeruhan tersebut telah banyak dilakukan, namun analisis abrasi dan kekeruhan dengan menggunakan pemodelan transpor sedimen secara numerik belum pernah dilakukan di daerah tersebut. Oleh karena itu pada penelitian ini telah dilakukan pemodelan hidrodinamika dan transpor sedimen untuk membuktikan adanya proses abrasi, sedimentasi, dan kekeruhan di sekitar Tanjung Pontang. Berdasarkan analisis tersebut maka dapat ditentukan saran untuk mengatasi permasalahan yang ada.

\section{BAHAN DAN METODE}

Pemodelan hidrodinamika dan transpor sedimen pada penelitian ini dilakukan di Perairan Utara Kabupaten Serang yang meliputi Teluk Banten, Pulau Panjang, Tanjung Pontang, Desa Lontar, dan Desa Tengkurak (Sungai Ciujung Baru). Daerah penelitian tersebut berada pada posisi $106,0935^{\circ} \mathrm{BT}-106,433^{\circ} \mathrm{BT}$ dan

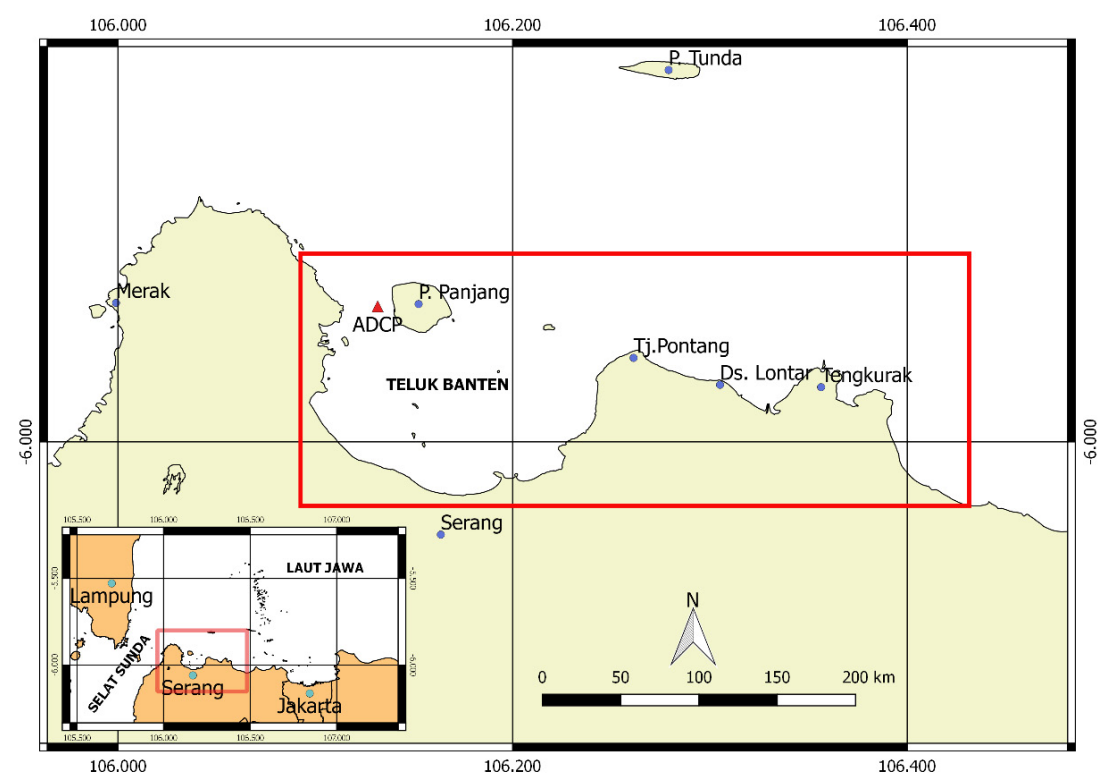

Gambar 1. Lokasi penelitian yang akan dimodelkan berada dalam lingkup kotak berwarna merah. Titik segitiga merah ADCP adalah posisi pengukuran arus dan pasut untuk validasi model.

Figure 1. Research location for hidrodynamic modeling is inside the scope of the red rectangle. The red triangle ADCP is the position of current and tide measurement for model validation.

Sumber: Hasil Pengolahan Data.

JURNAL KELAUTAN NASIONAL, Vol. 13, No 2, Agustus 2018, Hal. 75-88 
6,037 ${ }^{\circ} \mathrm{LS}-5,9072^{\circ} \mathrm{LS}$ yang pada Gambar 1 ditunjukkan oleh area di dalam kotak berwarna merah.

Data yang digunakan dalam pemodelan ini adalah data Batimetri, Angin, Arus, Pasang Surut, Total Suspension Sediment (TSS) dan analisis Sampel Sedimen. Data batimetri diperoleh dari peta LPI (Bakosurtanal \& Dishidros TNI-AL, 1999) yang diasimilasi dengan hasil pemeruman batimetri oleh Pusat Riset KelautanKKP yang dilakukan pada tahun 2014. Begitu juga dengan data arus, pasang surut, TSS dan sampel sedimen juga diperoleh dari Pusat Riset Kelautan KKP yang dilakukan pada tahun 2014. Data angin per 3 jam tahun 2007-2016 diunduh dari National Oceanic and Atmospheric Administration National (NOAA) Climatic Data Center (NCDC) dengan posisi di stasiun Meteorologi Serang, Banten. Data angin tersebut merupakan data pengukuran stasisun meteorologi di darat yang dikirimkan ke NCDC karena Indonesia termasuk ke dalam anggota World Meteorological Organization (WMO) di bawah Perserikatan Bangsa Bangsa (PBB) (NCDC, 2018; Aldrian, 2001).

Pemodelan hidrodinamika pada penelitian ini dilakukan dengan menggunakan perangkat lunak MIKE21 untuk mengetahui karakteristik hidrodinamika (Nugraha et al., 2014) serta transpor sedimen dengan menggunakan arus gelombang (Sufyan et al., 2017) pada daerah kajian. Mesh yang digunakan pada penelitian ini adalah Flow Model Flexible Mesh (Flow Model FM) seperti yang digunakan oleh Wisha et al. (2018). Model tersebut dijalankan dengan menggunakan modul Hydrodynamic Module (HD) (Mustikasari et al., 2015), Spectral Wave (SW), Sand Transport Module (ST), dan Mud Transport Module (MT). Modul SW dan ST digunakan untuk mengetahui perubahan bed level di sekitar Tanjung Pontang, sedangkan modul SW dan MT digunakan untuk mengetahui transpor sedimen melayang yang berkaitan dengan kekeruhan di perairan di sekitar Teluk Banten, Tanjung Pontang, hingga Sungai Ciujung baru di Desa Tengkurak. Parameter pemodelan hidrodinamika yang digunakan pada penelitian ini dapat dilihat pada Tabel 1. Periode simulasi hidrodinamika yang dijalankan menyesuaikan dengan waktu pengukuran arus dan pasang surut di lapangan, yaitu tanggal 1 September 2014 s.d 1 Oktober 2014.

Domain model hidrodinamika yang digunakan dalam penelitian ini dapat dilihat pada Gambar 2. Domain model terdiri dari tiga batas terbuka, yaitu $\mathrm{BC} 1, \mathrm{BC} 2$, dan $\mathrm{BC} 3$ dengan $\mathrm{BC} 1$ di sebelah barat, BC2 di utara, dan BC3 di timur. Elevasi air pada batas terbuka tersebut dibangkitkan dari hasil prediksi pasang surut yang diperoleh dari Tide Prediciton Height di perangkat lunak MIKE21 dengan periode yang sama dengan

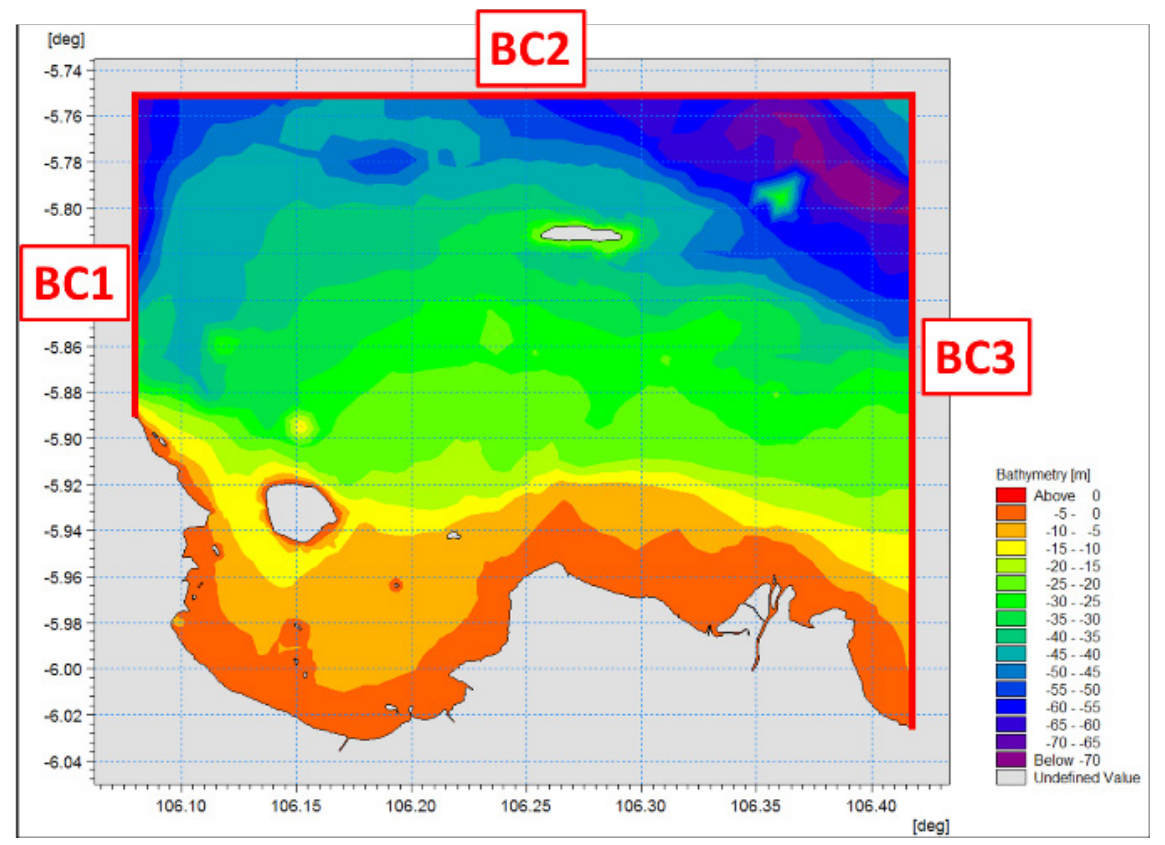

Gambar 2. Domain model hidrodinamika Perairan Utara Kabupaten Serang. $\mathrm{BC} 1, \mathrm{BC} 2, \mathrm{BC} 3$ adalah batas terbuka. Kontur menunjukkan batimetri.

Figure 2. Domain of hidrodynamic model in north water of Serang District. $B C 1, B C 2, B C 3$ are open boundary of model. Contour shows the bathimetry. Sumber: Hasil pengolahan data. 


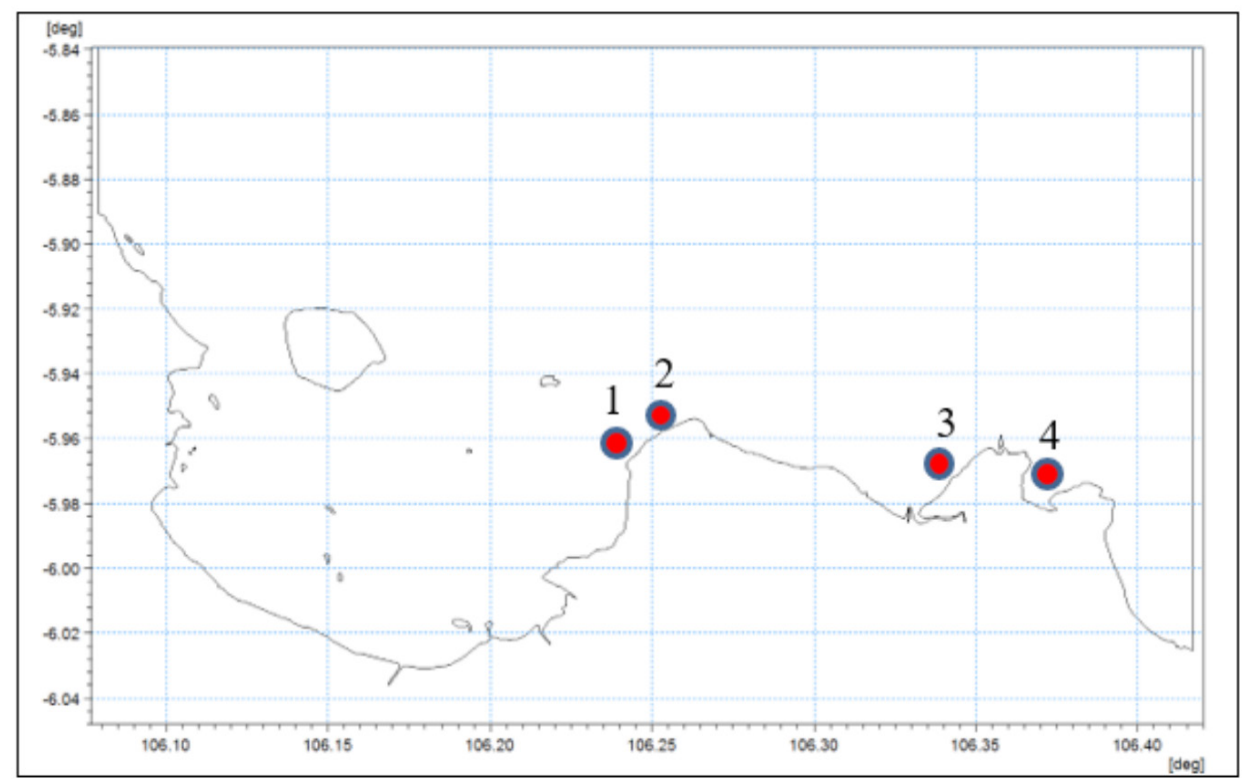

Gambar 3. Lokasi stasiun observasi virtual untuk analisis potensi abrasi dan sedimentasi di sekitar Tanjung Pontang dan muara Sungai Ciujung Baru.

Figure 3. Location of virtual observation stations for analysis abrasion and sedimentation around Pontang Cape and Ciujung Baru River estuary.

Sumber: Hasil pengolahan data.

periode simulasi.

Hasil pemodelan hidrodinamika modul HD yang masih tanpa parameter angin divalidasi menggunakan data pengukuran arus dan pasang surut yang diukur di sebelah barat Pulau Panjang dengan koordinat $106,1316^{\circ} \mathrm{BT} ; 5,9314^{\circ} \mathrm{LS}$ (Gambar 1) selama 30 hari, dimulai dari tanggal 1 September 2014 s.d 1 Oktober 2014. Data arus dan pasang surut tersebut diukur menggunakan Acoustic Doppler Current Profiler (ADCP) dengan tipe Nortek Aquadopp. Tujuan dari validasi ini adalah untuk mengetahui sejauh mana tingkat kredibilitas model yang dijalankan. Jika error antara model dengan hasil pengukuran cukup kecil maka model dapat digunakan, namun jika error antara model dengan hasil pengukuran cukup besar maka perlu dilakukan pengaturan parameter-parameter input model hingga diperoleh error yang kecil antara model dan pengukuran.

Pemodelan transpor sedimen dilakukan dengan memodelkan arus dengan menambahkan parameter angin. Parameter angin yang digunakan adalah angin yang mempunyai frekuensi kejadian dan kecepatan yang tinggi di daerah penelitian. Asumsi yang digunakan pada pemodelan sedimen transpor yaitu angin bergerak dengan arah dan kecepatan yang konstan berdasarkan hasil analisis data angin selama simulasi dijalankan. Pada penelitian ini juga diasumsikan bahwa arus akibat pasang surut pada tiap bulan atau tiap musim mempunyai pola dan kecepatan arus yang sama, hanya angin saja yang berubah baik arah dan juga kecepatannya. Parameter angin menjadi penting pada pemodelan transpor sedimen ini karena angin merupakan parameter yang mempunyai peran besar dalam interaksi laut dan atmosfer termasuk arus laut (Wibisono, 2005; Syafik et al., 2013) dan arus laut mempunyai peran besar terhadap transpor sedimen (Dronkers, 2005; Rachmat \& Purwanto, 2011).

Arus laut hasil pemodelan yang menggunakan parameter angin tersebut diukur nilai kecepatannya pada stasiun observasi virtual di sekitar Tanjung Pontang pada musim barat dan musim timur. Stasiun observasi virtual yang dimaksud dapat dilihat pada Gambar 3

Analisis abrasi di sekitar Tanjung Pontang dilakukan dengan mengukur perubahan bed level di stasiun obervasi virtual (Gambar 3) selama simulasi yang dilakukan selama 16 hari yaitu pada siklus pasang surut purnama. Parameter sedimen yang digunakan untuk analisis abrasi ini adalah nilai rata-rata diameter sedimen yang lolos $50 \%$ (d50) dari semua sampel sedimen yang diambil di sekitar Tanjung Pontang. Dengan demikian parameter besar butir sedimen d50 tersebut dianggap dapat mewakili ukuran sedimen di perairan di sekitar Tanjung Pontang.

Analisis kekeruhan di sekitar Tanjung Pontang 
dilakukan dengan menggunakan model hidrodinamika yang ditambahkan parameter angin. Pada analisis kekeruhan ini data TSS digunakan sebagai input konsentrasi sedimen melayang pada sungai-sungai di Teluk Banten, Tanjung Pontang hingga Desa Tengkurak. Setiap sungai pada pemodelan ini diasumsikan mempunyai debit air yang sama dan konstan yaitu sebesar $120 \mathrm{~m}^{3} /$ detik. Parameter pemodelan transpor sedimen ini dapat dilihat pada Tabel 1.

\section{HASIL DAN PEMBAHASAN}

Hasil pemodelan hidrodinamika tanpa parameter angin divalidasi dengan data kecepatan arus dan pasang surut hasil pengukuran ADCP. Perbandingan antara pasang surut hasil pemodelan dengan pengukuran (Gambar 4) menunjukkan pola yang sama meskipun terdapat selisih amplitudo yang relatif kecil, yaitu dengan nilai RMS Error sebesar 6,9\%, dan korelasi sebesar $91,07 \%$. Demikian juga perbandingan kecepatan arus komponen U (Gambar 5.a) dan Komponen V (Gambar 5.b) menunjukkan pola yang mirip dengan selisih amplitudo yang juga relatif kecil. Nilai RMS error komponen U sebesar 12,17\%, dengan korelasi 83,42 $\%$ dan Komponen V mempunyai nilai RMS error sebesar 3,5\%, dengan korelasi sebesar 59,3\%.

Error tersebut muncul mungkin diakibatkan oleh adanya pengaruh faktor luar seperti angin dan gelombang pada data ADCP (Wisha et al., 2015; Triatmodjo, 2011). Dengan demikian hasil validasi tersebut menunjukkan error yang cukup kecil dan korelasi yang kuat antara model dengan data pengukuran, sehingga dapat dikatakan bahwa model hidrodinamika ini telah mendekati kondisi sebenarnya dan dapat digunakan untuk menganalisis kondisi arus dan transpor sedimen pada penelitian ini (Sugiyono, 2014, Novico et al, 2013).

Hasil pemodelan hidrodinamika arus pasang surut dapat dilihat pada Gambar 6 dan Gambar 7. Pada Gambar-gambar tersebut ditampilkan pola arus perairan saat pasang purnama, dan surut purnama. Hal itu dilakukan karena pada saat pasang dan surut purnama, arus mempunyai kecepatan yang tinggi akibat elevasi pasang surutnya yang tinggi (Husrin et al., 2014).

Pada kondisi pasang purnama (Gambar 6), arus di perairan teluk Banten bergerak meninggalkan pantai ke arah barat dengan kecepatan 0,02-0,18 m/s. Namun kondisi arus di luar teluk bergerak ke arah timur. Nilai kisaran kecepatan arus pada saat pasang purnama
Tabel 1. Parameter setup pemodelan

Table 1. Parameters of modelling setup

\begin{tabular}{|c|c|}
\hline Parameter & Diterapkan dalam simulasi \\
\hline \multicolumn{2}{|c|}{ HD Module } \\
\hline Mesh and Bathymetry & Hasil interpolasi mesh \\
\hline \multirow[t]{4}{*}{ Simulation Period } & No. of timestep $=720$ \\
\hline & Time Step Interval $=3600 \mathrm{~s}$ \\
\hline & Simulation start date $=1 / 9 / 2014$ \\
\hline & Simulation end date $=1 / 10 / 2014$ \\
\hline \multirow[t]{3}{*}{ Flood and Dry } & Drying depth $=0,005 \mathrm{~m}$ \\
\hline & Flooding Depth $=0,05 \mathrm{~m}$ \\
\hline & Wetting Depth $=0,1 \mathrm{~m}$ \\
\hline Bed Resistence & Manning $=28 \mathrm{~m}^{1 / 3}$ \\
\hline Initial Condition & $-0.14548 \mathrm{~m}$ \\
\hline Boundary condition & Hasil Prediksi Tiap Boundary \\
\hline
\end{tabular}

SW Module

\begin{tabular}{ll}
\hline Water Level Condition & Hasil HD Module \\
Current Condition & Hasil HD Module \\
Wind Forcing & Musim Barat \\
& Wind Speed $=8,8 \mathrm{~m} / \mathrm{s}$ \\
& Wind Direction $=2700$ \\
& Musim Timur \\
& Wind Speed $=8,8 \mathrm{~m} / \mathrm{s}$ \\
& Wind Direction $=3600$
\end{tabular}

ST Module

\begin{tabular}{ll}
\hline Sediment Properties & $\begin{array}{l}\text { Porositas }=0,4 \\
\text { Grain Diameter }(\mathrm{d} 50)=0,6 \mathrm{~mm} \\
\\
\text { Grading Coefficient }=1,1\end{array}$ \\
Forcing & Hasil SW Module
\end{tabular}

MT Module

\begin{tabular}{ll}
\hline Forcing & Hasil SW Module dan HD \\
& Module \\
Kource & Konsentrasi \\
& Ciujung Lama $=283 \mathrm{mg} / 1$ \\
& Ciujung Baru $=84 \mathrm{mg} / 1$ \\
& Cikeumayungan $=23 \mathrm{mg} / 1$ \\
& Kali Anyar $=23 \mathrm{mg} / 1$ \\
& Kali Banten $=19 \mathrm{mg} / 1$ \\
\hline
\end{tabular}

Sumber: Hasil pengolahan data

tersebut tidak jauh berbeda dengan hasil penelitian oleh Wisha et al. (2015) yang mengatakan kecepatan arus di Teluk Banten saat pasang purnama berkisar $0,02-0,01 \mathrm{~m} / \mathrm{s}$.

Pada kondisi surut purnama (Gambar 7), arus bergerak ke dalam teluk dan menuju ke arah timur, namun juga terdapat arus yang begerak dari arah timur sehingga 


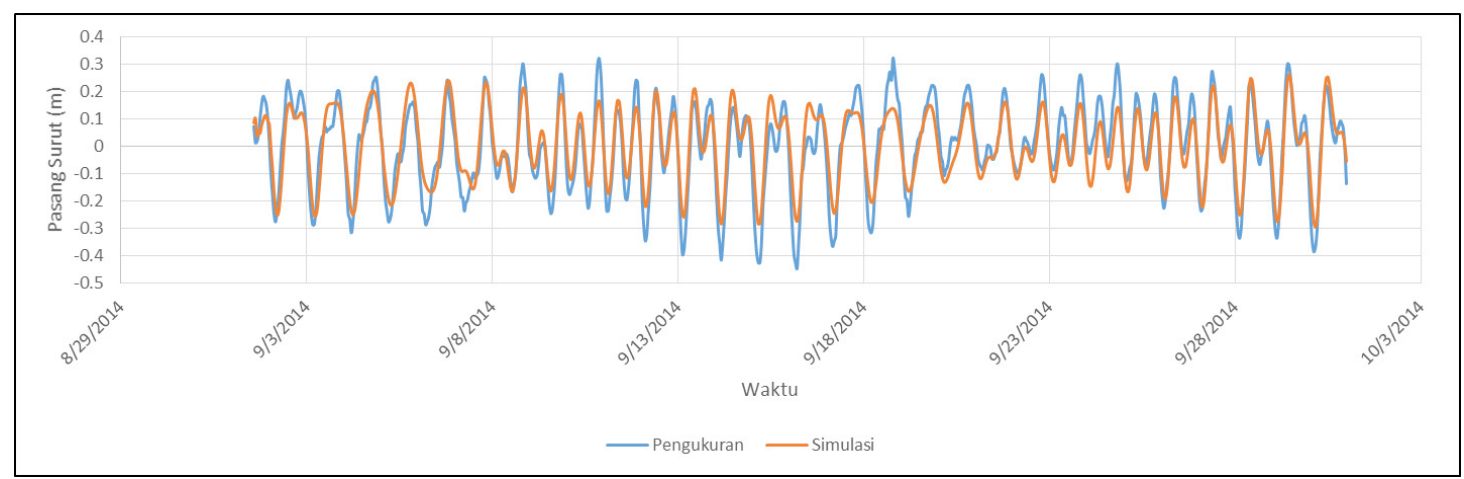

Gambar 4. Perbandingan pasang surut pemodelan dengan pengukuran. Korelasi $=91,07 \%$, RMS Error $=6,9 \%$.

Figure 4. Comparison of tidal modeling against measurement. Correlation=91,07\%, RMS Error=6,9\%. Sumber: Hasil pengolahan data.
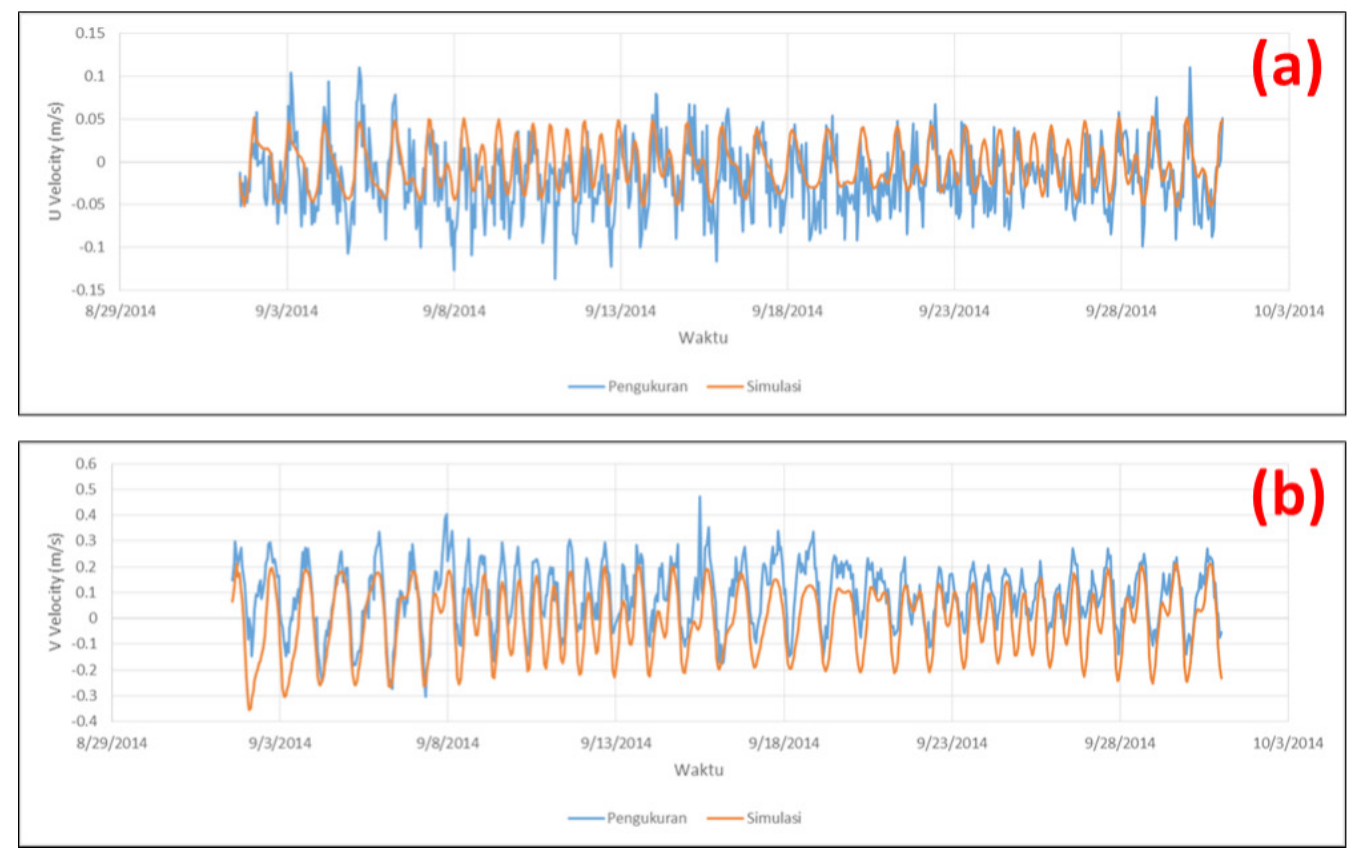

Gambar 5. (a)Perbandingan komponen arus $U$ hasil pemodelan dengan hasil pengukuran. korelasi $=83,42 \%$, dan RMS Error $=12,17 \%$. (b) Perbandingan komponen arus $\mathrm{V}$ hasil pemodelan dengan hasil pengukuran. korelasi $=59,3 \%$ dan RMS Error $=3,5 \%$.

Figure 5. (a)comparison of $U$ current component from model with the measurement data. correlation $=83.42 \%$, and $R M S$ Error $=12.17 \%$. (b) comparison of $V$ current component from model with the measurement data. Correlation $=59.3 \%$ and $R M S$ Error $=3.5 \%$.

arus bergerak ke arah utara dengan kecepatan 0,04$0,56 \mathrm{~m} /$ detik. Hasil tersebut tidak jauh berbeda dengan penelitian yang dilakukan oleh Wisha et al. (2015) yang mengatakan bahwa kecepatan arus di Teluk Banten pada saat surut purnama berkisar 0,03-0,08 m/ detik. Perbedaan kisaran nilai kecepatan antara model dalam penelitian ini dengan yang dilakukan Wisha et al. (2015) cukup kecil.

Model transpor sedimen dijalankan dengan menggunakan model hidrodinamika yang ditambahkan parameter angin. Parameter angin tersebut meliputi arah dan kecepatan yang diperoleh dari analisis data angin di
Serang. Hasil analisis menunjukkan bahwa terdapat dua arah angin yang dominan di sekitar Kabupaten Serang dari tahun 2007-2016, yaitu angin dari barat dan angin dari utara. Angin dari barat adalah angin yang paling dominan karena mempunyai frekuensi kejadian dan kecepatan paling tinggi. Frekuensi kejadian angin barat ini mencapai $23 \%$, dengan kecepatan maksimum 8,8 $\mathrm{m} /$ detik. Angin barat ini terjadi pada bulan Desember, Januari, dan Februari yang biasa disebut dengan musim barat (Wyrtki, 1961). Dominasi yang kedua adalah angin yang bergerak dari arah utara dengan frekuensi kejadian mencapai 13\% dengan kecepatan maksimum $8,8 \mathrm{~m} /$ detik. Angin ini terjadi pada bulan Juni, Juli, dan 


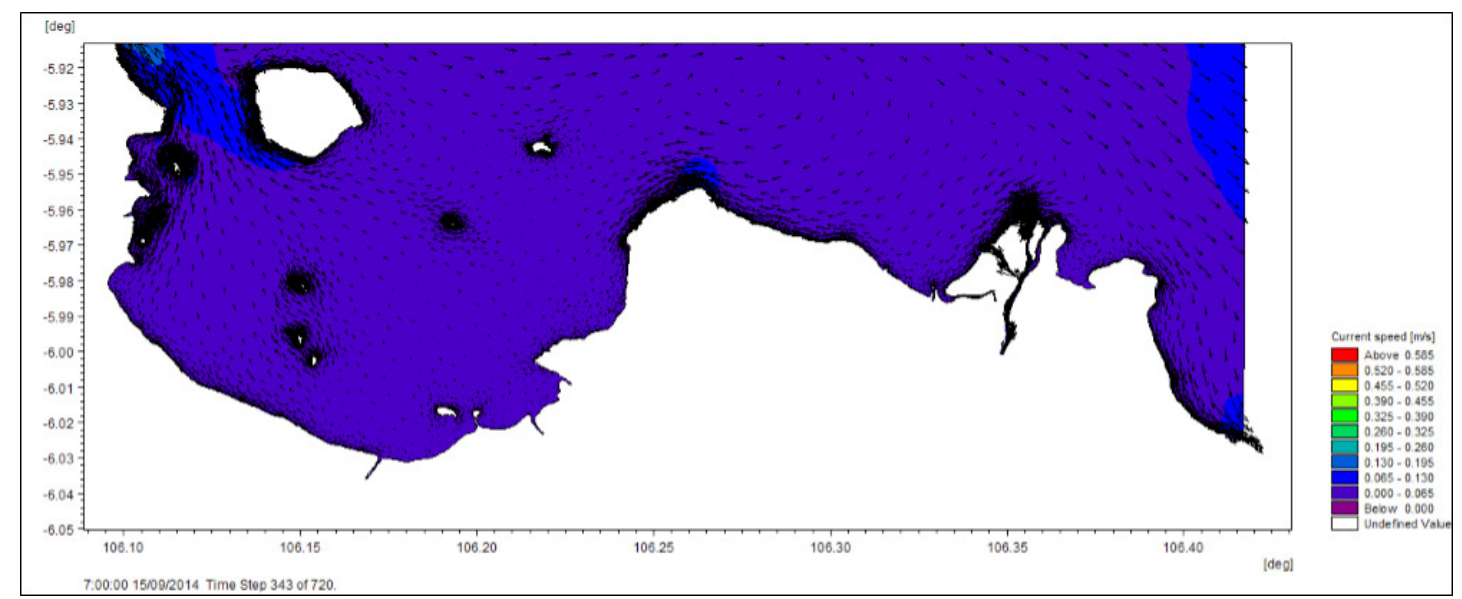

Gambar 6. Pola arus saat kondisi pasang purnama pada domain model utama.

Figure 6. Pattern of current circulation during high spring tide at main domain modeling Sumber: Hasil pengolahan data

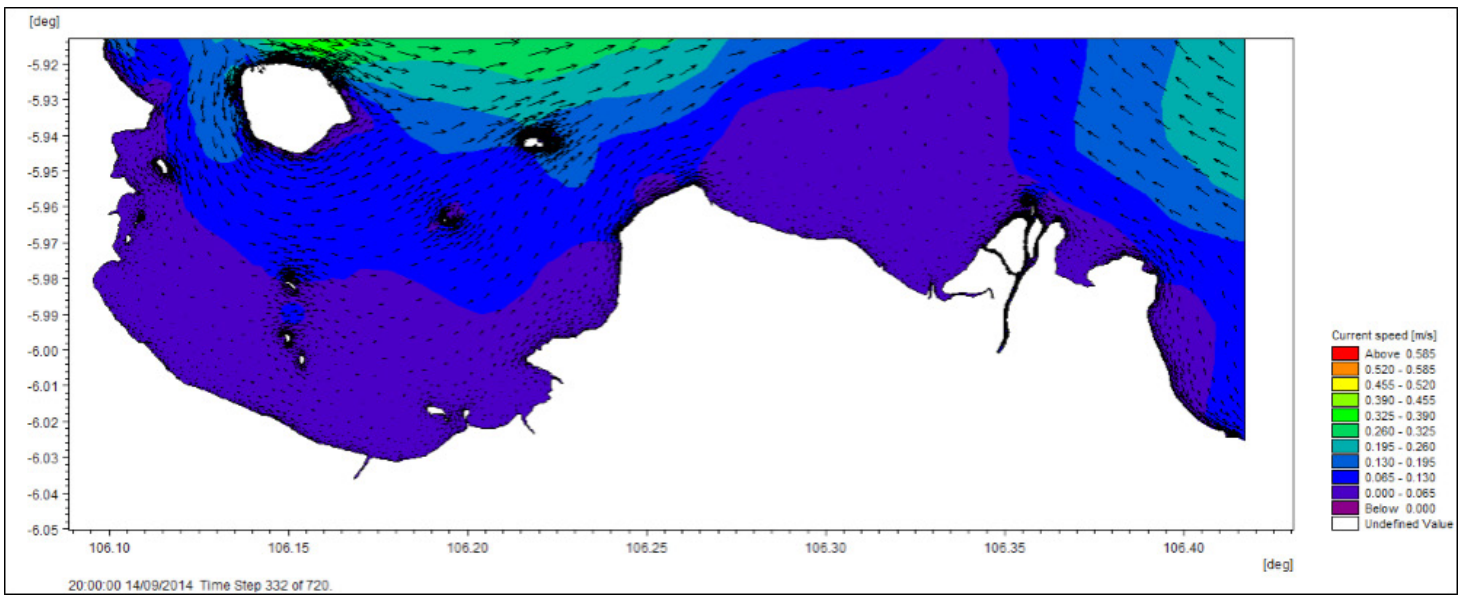

Gambar 7. Pola arus saat kondisi surut purnama pada domain model utama.

Figure 7. Pattern of current circulation during low spring tide at main domain modeling Sumber: Hasil pengolahan data.

Agustus dan biasa disebut sebagai angin musim timur (Wyrtki, 1961). Diagram mawar data angin di Serang pada tahun 2007 - 2016 dapat dilihat pada Gambar 8.

Pola arus akibat pengaruh angin musim timur dan pasang surut ditunjukkan oleh Gambar 9 dan Gambar 10. Hasil pemodelan menunjukkan bahwa pola arus di sekitar Tanjung Pontang pada saat musim timur dan pasang purnama (Gambar 9) arus bergerak sejajar pantai dengan sebagian arah arus bergerak sejajar pantai di timur Tanjung Pontang menuju arah Desa Lontar, dan sebagian bergerak sejajar pantai dari Tanjung Pontang menuju Teluk Banten. Pada saat Surut Purnama (Gambar 10) arus di sekitar Tanjung Pontang mempunyai pola yang tidak jauh berbeda dengan pola arus saat Pasang Purnama. Perbedaannya hanya pada nilai kecepatan arusnya saja. Pada saat pasang purnama kecepatan arus di Tanjung Pontang berkisar 0,025 - 0,2 $\mathrm{m} /$ detik, sedangkan pada saat surut purnama berkisar antara $0-0,4 \mathrm{~m} /$ detik.

Pola arus akibat musim barat ditunjukkan oleh Gambar 11 dan Gambar 12. Hasil pemodelan menunjukkan bahwa arus di sekitar Tanjung Pontang pada saat pasang purnama (Gambar 11) dan surut purnama (Gambar 12) arus sama-sama bergerak sejajar garis pantai yang bergerak keluar dari Teluk Banten menuju utara ke Tanjung Pontang dan berlanjut ke timur menuju Desa Lontar. Kecepatan arus pada saat pasang purnama berkisar $0-0,3 \mathrm{~m} /$ detik, sedangkan pada saat surut purnama berkisar $0-0,4 \mathrm{~m} /$ detik.

Analisis potensi terjadinya abrasi serta sedimentasi di sekitar Tanjung Pontang dibuktikan dengan meninjau kecepatan arus pada musim timur dan musim barat dan melakukan analisis perubahan bed level pada empat stasiun observasi virtual. 


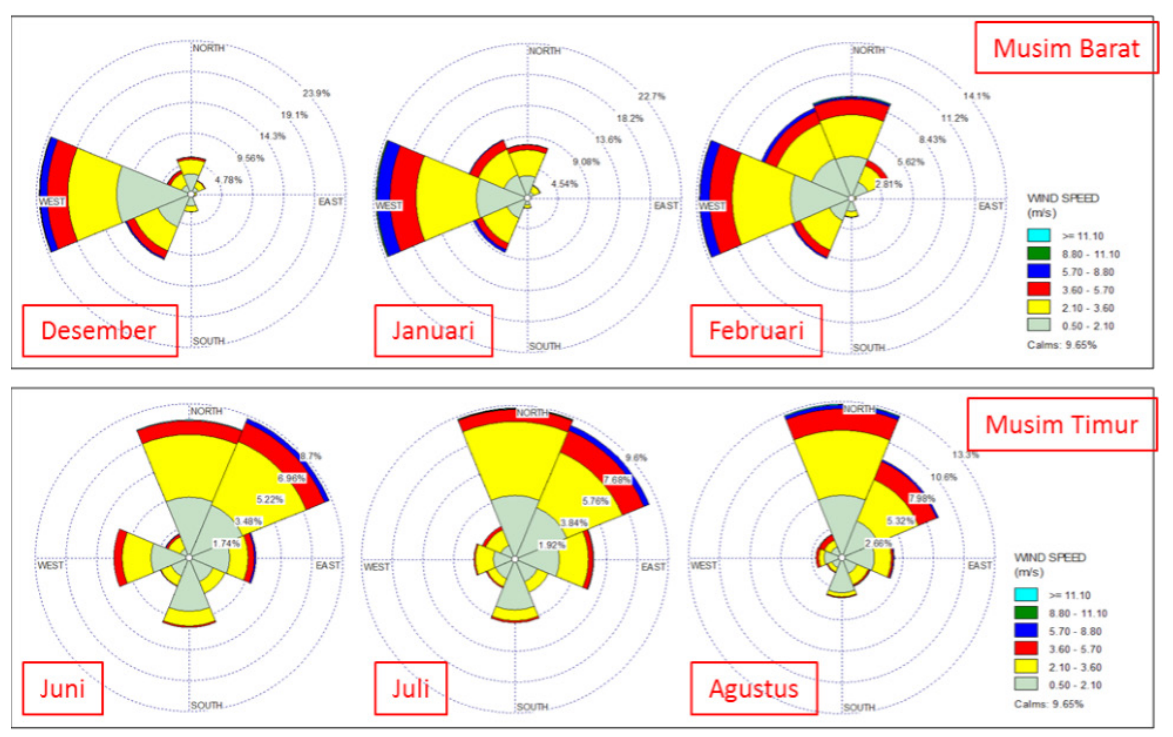

Gambar 8. Karakteristik angin tahun 2007-2016 di musim barat dan timur pada Stasiun Serang.

Figure 8. Wind characteristic of 2007-2016 during west and east monsoons at Serang Station Sumber: Hasil pengolahan data NCDC NOAA

Perbandingan nilai kecepatan arus laut di stasiun observasi virtual pada saat musim barat dan musim timur ditunjukkan pada Gambar 13. Hasil perbandingan tersebut menunjukkan bahwa arus pada stasiun observasi virtual nomor 1,2, dan 3 pada musim barat lebih besar dibanding pada musim timur, sedangkan pada stasiun observasi virtual nomor 4 arus pada musim barat dan musim timur mempunyai nilai kecepatan yang sama.

Menurut Dronkers (2005) arus perairan dengan nilai kecepatan di atas $0,1 \mathrm{~m} /$ detik dapat mengangkut sedimen yang berdiameter $0,6 \mathrm{~mm}$ sehingga berpotensi menyebabkan abrasi di daerah tersebut. Berdasarkan analisis kecepatan arus di empat stasiun observasi virtual yang telah ditentukan, dapat diketahui bahwa pada stasiun observasi virtual nomor 1, 2, dan 3 berpotensi terjadi abrasi pada musim barat dan juga musim timur karena mempunyai kecepatan rata-rata di atas $0,1 \mathrm{~m} /$ detik. sedangkan pada stasiun observasi virtual nomor 4 tidak berpotensi terjadi abrasi karena nilai kecepatan arusnya di bawah $0,1 \mathrm{~m} /$ detik.

Hasil ini ditindaklanjuti dengan melakukan analisis perubahan bed level di stasiun observasi virtual yang telah ditentukan, namun hanya menggunakan arus pada saat musim barat saja dengan tujuan untuk memodelkan abrasi dan sebaran transpor sedimen maksimumnya karena nilai kecepatan arus pada musim barat di stasiun observasi virtual nomor 1, 2 dan 3 mempunyai kecepatan lebih tinggi dan konsisten di atas $0,1 \mathrm{~m} /$ detik.
Analisis perubahan bed level tersebut digunakan untuk membuktikan terjadinya abrasi atau sedimentasi di suatu titik. Jika pada stasiun observasi virtual terjadi penurunan bed level seiring dengan waktu maka pada daerah itu dapat dikatakan dominan terjadi abrasi, sedangkan jika pada stasiun virtual observasi terjadi penambahan bed level maka pada daerah tersebut dominan terjadi sedimentasi (Novico et al., 2013).

Analisis perubahan bed level pada musim barat menunjukkan terjadinya penurunan bed level seiring dengan waktu bahwa pada stasiun observasi virtual 1 , 2 dan 3. Hal itu menunjukkan bahwa di daerah sekitar stasiun observasi virtual 1,2, dan 3 dominan terjadi abrasi. Besarnya penurunan bed level selama 16 hari pada stasiun observasi virtual 1 sebesar $0,17 \mathrm{~mm}$, stasiun observasi virtual 2 sebesar $2,73 \mathrm{~mm}$, dan stasiun observasi virtual 3 sebesar $2,21 \mathrm{~mm}$. berdasarkan hasil tersebut diketahui bahwa perubahan bed level terbesar berada di stasiun ovservasi virtual nomor 2. Sedangkan pada stasiun observasi virtual 4 menunjukkan adanya penambahan bed level seiring dengan waktu sebesar $9,83 \mathrm{~mm}$. Dengan demikian dapat dikatakan bahwa di sekitar stasiun observasi virtual 1, 2, dan 3 dominan terjadi abrasi, sedangkan pada stasiun ovservasi virtual 4 dominan terjadi sedimentasi. Grafik perubahan bed level di setiap stasiun pengamatan virtual dapat dilihat pada Gambar 14.

Berdasarkan analisis perubahan bed level di sekitar Tanjung Pontang hingga Sungai Ciujung Baru mengindikasikan adanya potensi abrasi di sekitar 


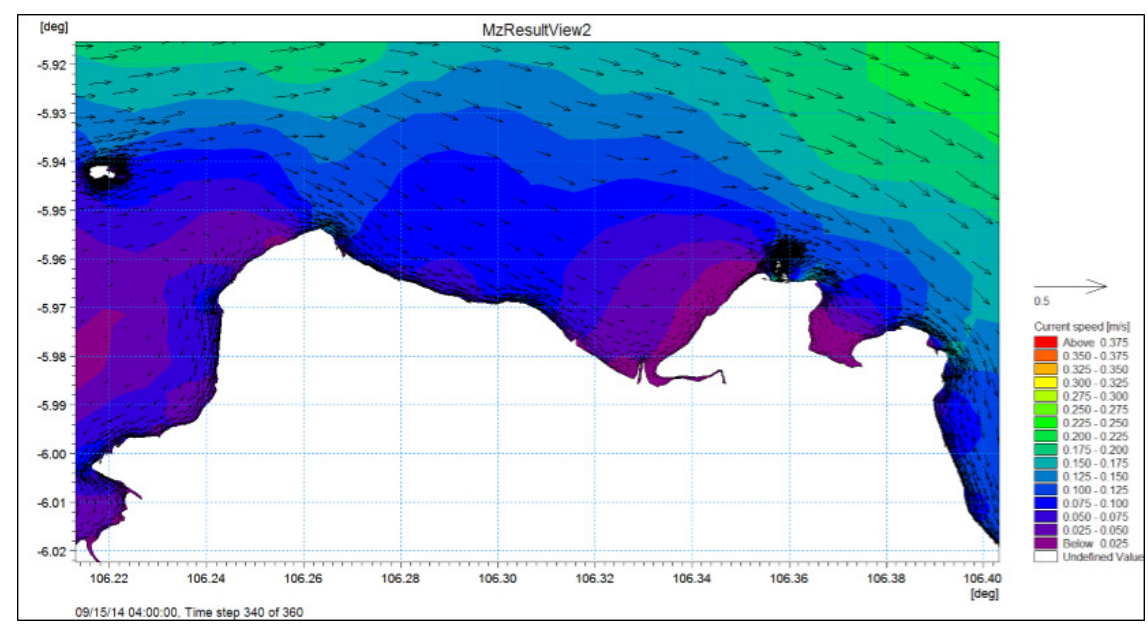

Gambar 9. Pola arus saat kondisi pasang purnama pada Musim Timur pada domain timur model.

Figure 9. Pattern of current circulation during high spring tide in East Monsoon at eastern part of model domain. Sumber: Hasil pengolahan data.

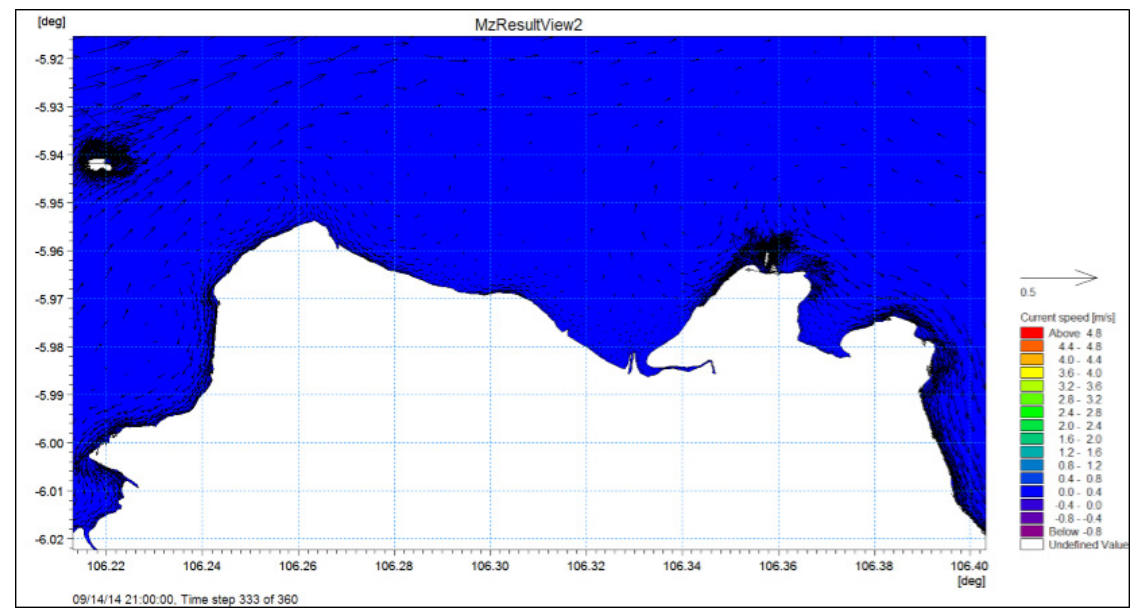

Gambar 10. Pola arus saat kondisi surut purnama pada Musim Timur pada domain timur model.

Figure 10. Pattern of current circulation during low spring tide in East Monsoon at eastern part of model domain.

Sumber: Hasil pengolahan data.

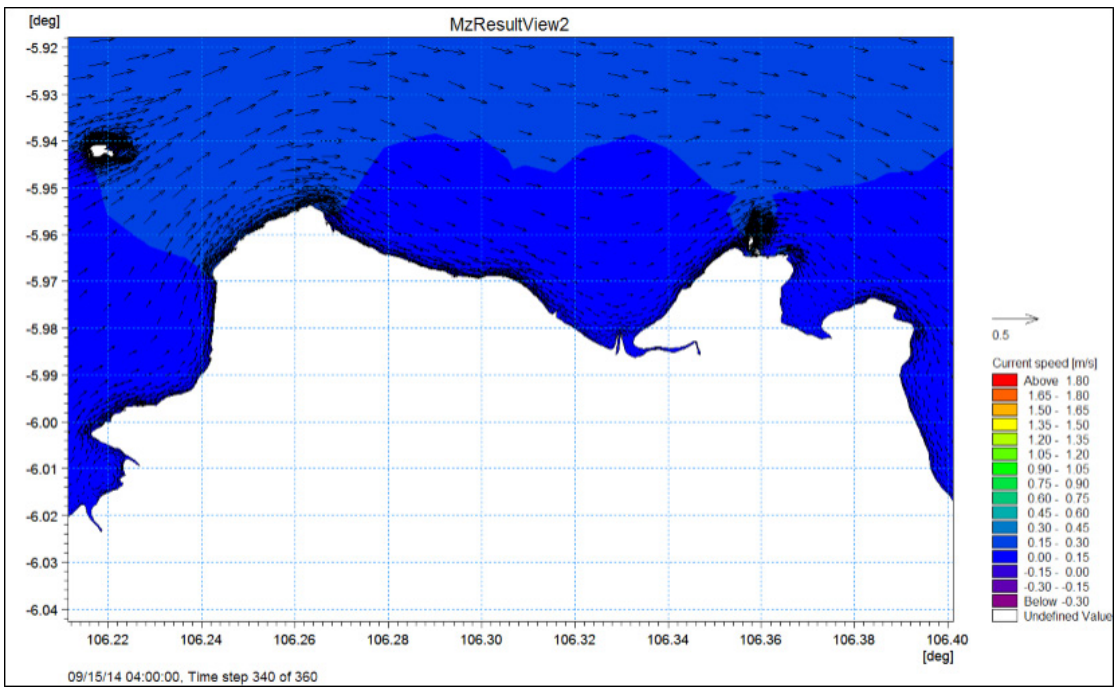

Gambar 11. Pola arus saat kondisi pasang purnama pada Musim Barat pada domain timur model.

Figure 11. Pattern of current circulation during high spring tide in West Monsoon at eastern part of mode domain. Sumber: Hasil pengolahan data. 


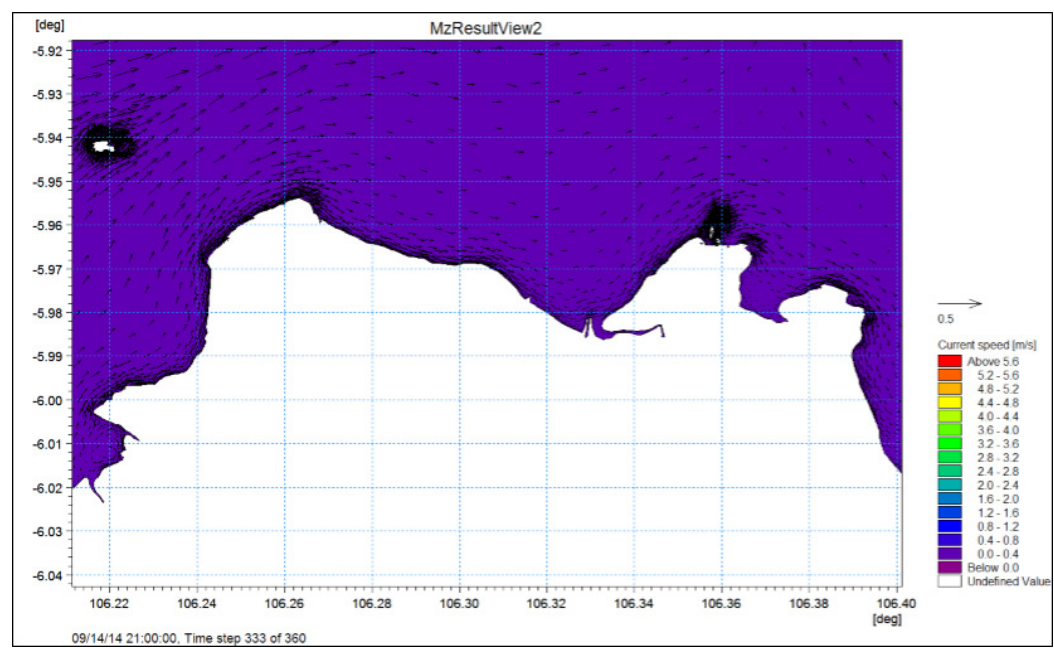

Gambar 12. Pola arus saat kondisi surut purnama pada Musim Barat pada domain timur model.

Figure 12. Pattern of current circulation during low spring tide in West Monsoon at eastern part of model domain. Sumber: Hasil pengolahan data.

Tanjung Pontang. Hasil pemodelan ini mendukung hasil penelitian-penelitian sebelumnya (Kusumawati, 2008; Husrin \& Prihantono, 2014; P3SDLP, 2014) yang menyatakan bahwa di daerah Tanjung Pontang terjadi abrasi dan sedimen tersebut tersedimentasi di sekitar daerah Sungai Ciujung Baru. Sedimen tersedimentasi di sungai Ciujung Baru karena pada daerah tersebut selain tersuplai sedimen dari sungai Ciujung Baru (Husrin et al., 2014) juga kemungkinan ditambah oleh sedimen yang terabrasi di Tanjung Pontang yang dibuktikan berdasarkan perubahan bed level.

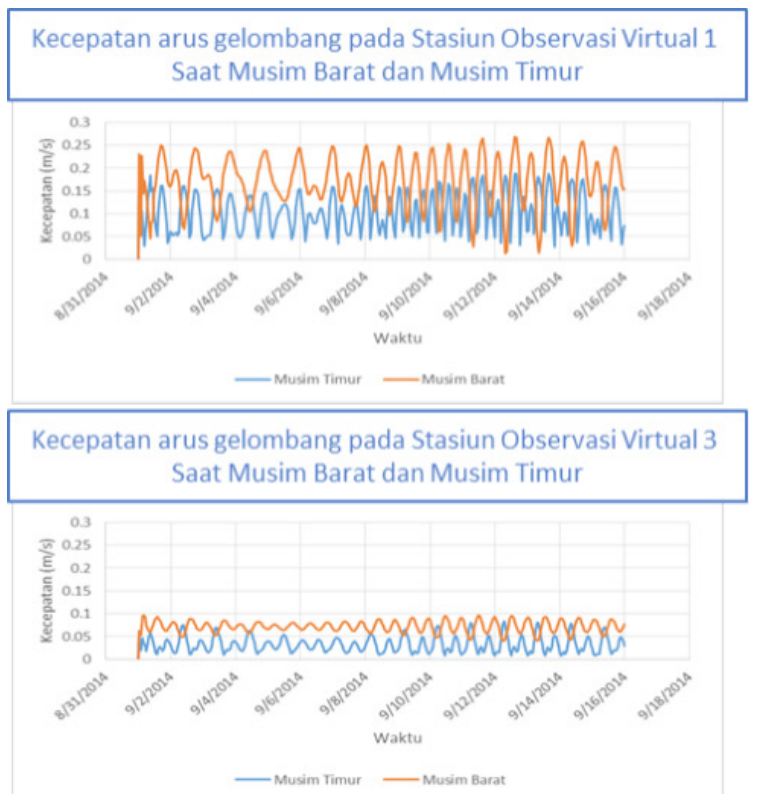

Analisis kekeruhan yang terjadi di sekitar Teluk Banten dan Tanjung Pontang dilakukan dengan memodelkan transpor sedimen melayang atau tersuspensi ditunjukkan pada Gambar 15 dan Gambar 16. Berdasarkan hasil pemodelan tersebut, kekeruhan di sekitar Tanjung Pontang, Desa Lontar, hingga Desa Tengkurak lebih banyak disebabkan oleh kontribusi dari Sungai Ciujung Lama di Tanjung Pontang. Sedangkan kekeruhan di Teluk Banten sangat kecil dibandingkan dengan kekeruhan yang terjadi di Tanjung Pontang hingga Desa Tengkurak. Hal itu terjadi karena pada pemodelan ini parameter angin yang digunakan hanya

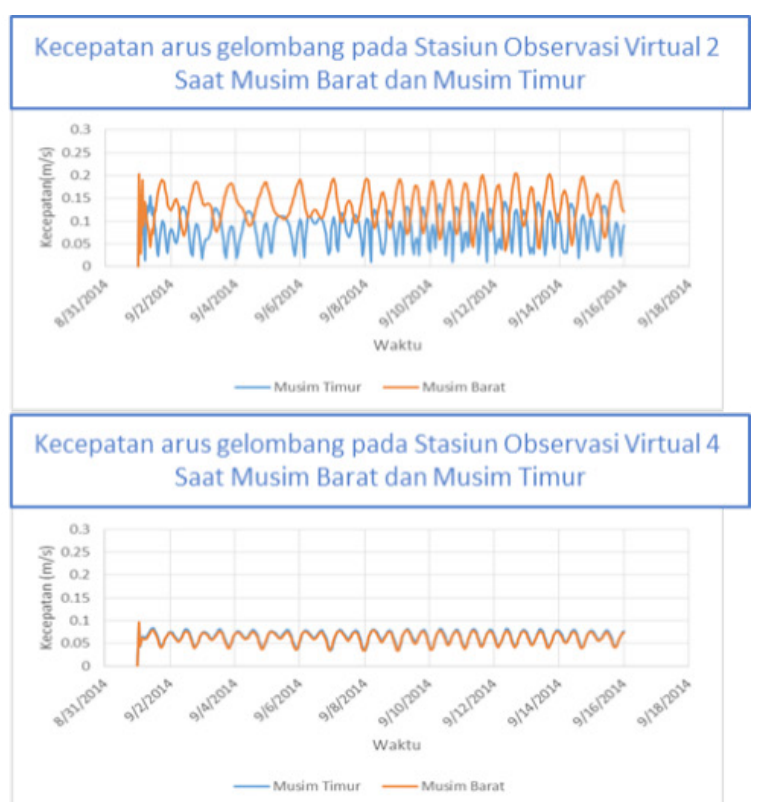

Gambar 13. Kecepatan arus akibat pengaruh angin musim barat (garis warna oranye) dan kecepatan arus akibat pengaruh angin musim timur (garis warna biru) pada stasiun observasi virtual.

Figure 13. Current velocity due to the influence of west monsoon (orange line) and current velocity due to the influence of east monsoon (blue line) at the virtual observation station.

Sumber: Hasil pengolahan data.

JURNAL KELAUTAN NASIONAL, Vol. 13, No 2, Agustus 2018, Hal. 75-88 

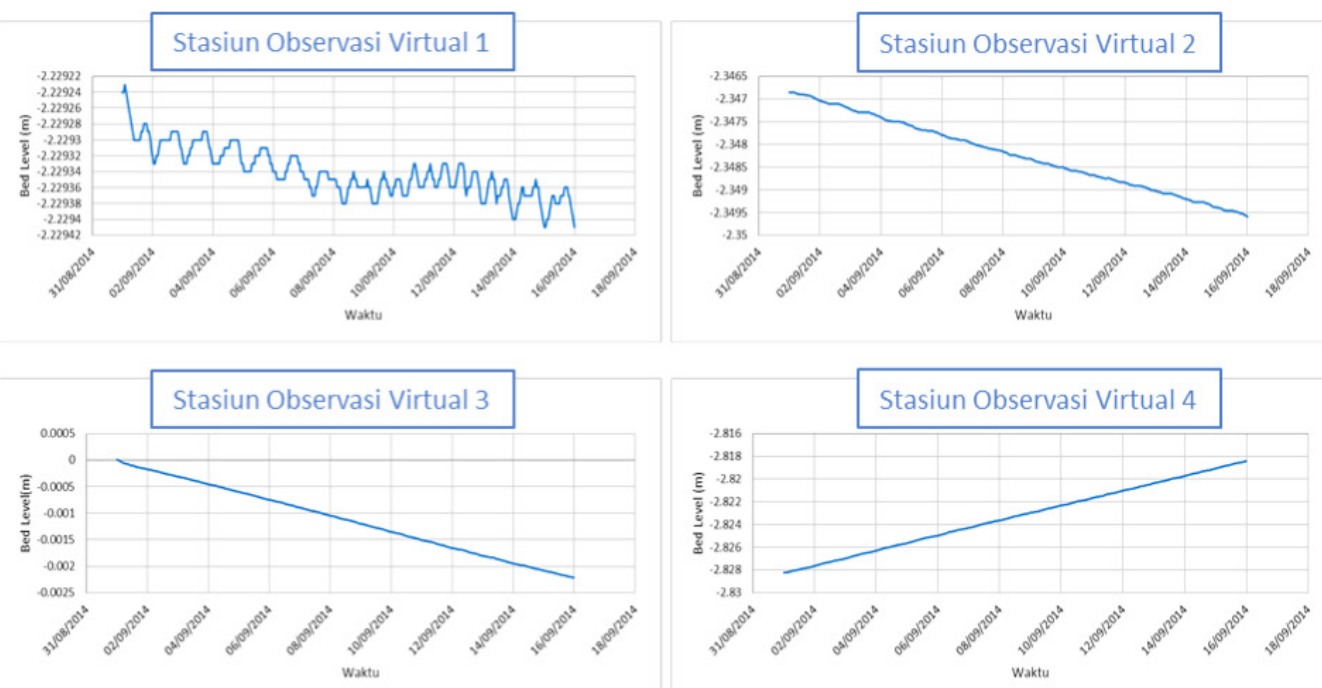

Gambar 14. Perubahan bed level pada lokasi stasiun observasi virtual.

Figure 14. Bed level change at virtual observation station.

Sumber: Hasil pengolahan data.

angin yang bergerak dari barat dengan arah dan kecepatan yang konstan.

Berdasarkan hasil model dapat diketahui bahwa sedimen melayang di sungai Ciujung Lama dapat tertransportasikan hingga ke sungai Ciujung Baru di Desa Tengkurak. Namun kekeruhan tinggi berada di sekitar Tanjung Pontang hingga Desa Lontar. Nilai kekeruhan pada saat surut purnama lebih tinggi dibandingkan pada saat pasang purnama. Nilai kekeruhan pada saat surut Purnama berkisar antara $1,186 \times 10^{-10}-3,586 \times 10^{-10} \mathrm{Kg} / \mathrm{m}^{3}$ sedangkan pada saat pasang purnama berkisar antara $6,949 \times 10^{-11}-3,495 \times 10$ ${ }^{10} \mathrm{Kg} / \mathrm{m}^{3}$.

Berdasarkan hasil penelitian tersebut dapat diketahui bahwa Sungai Ciujung Lama di Tanjung Pontang mempunyai kontribusi yang besar terhadap kekeruhan di Teluk Banten dan di sekitar Tanjung Pontang dibandingkan dengan sungai lainnya. Hasil pemodelan ini telah membuktikan penelitian sebelumnya (Hoekstra et al., 2003; Hoitink \& Hoekstra, 2003; Wisha et al., 2015; P3SDLP, 2014) yang menyatakan bahwa kekeruhan di teluk Banten terjadi karena adanya transpor sedimen di Sungai Ciujung Lama yang ada di Tanjung Pontang.

Tanjung Pontang secara alami telah mengalamai erosi sejak abad ke-19 karena adanya pengalihan aliran sungai yang semula bermuara di Sungai Ciujung lama di Tanjung Pontang dialihkan ke muara Ciujung yang baru di Desa Tengkurak (Ongkosongo \& Wijinarko,

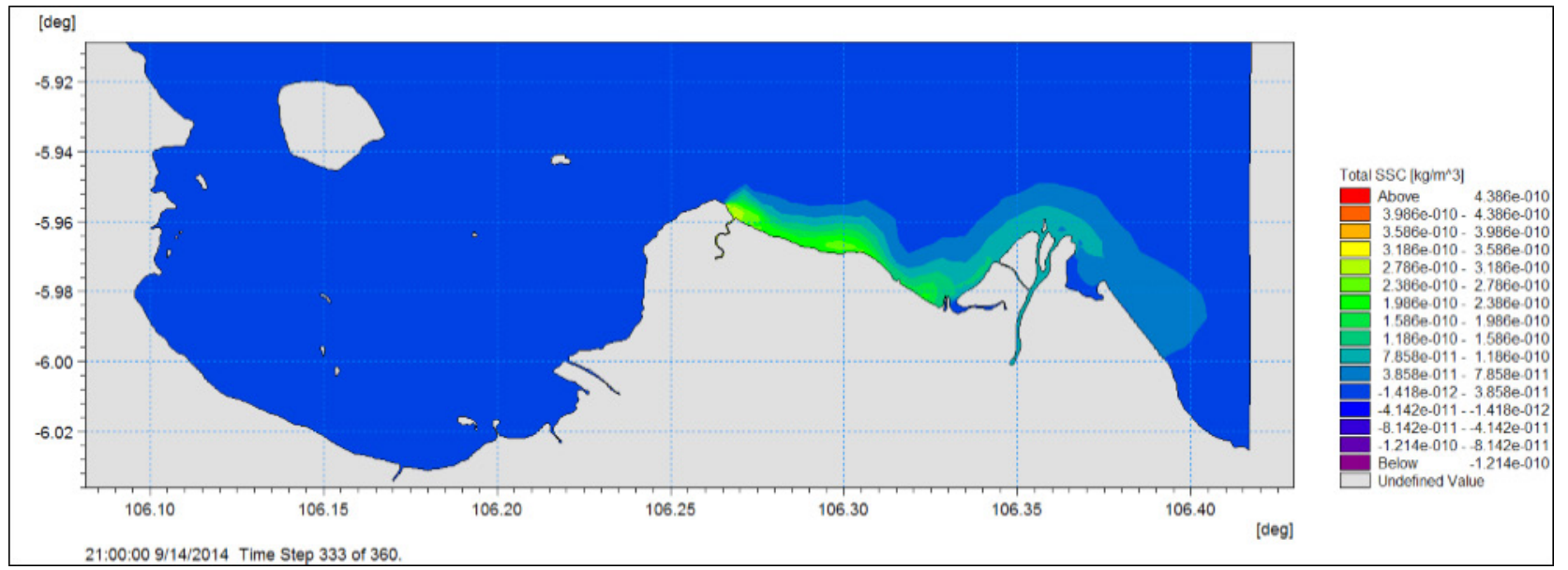

Gambar 15. Transpor sedimen layang saat kondisi surut purnama pada domain utama model.

Figure 15. Suspended sediment transport during low spring tide at main modeling domain. Sumber: Hasil pengolahan data. 


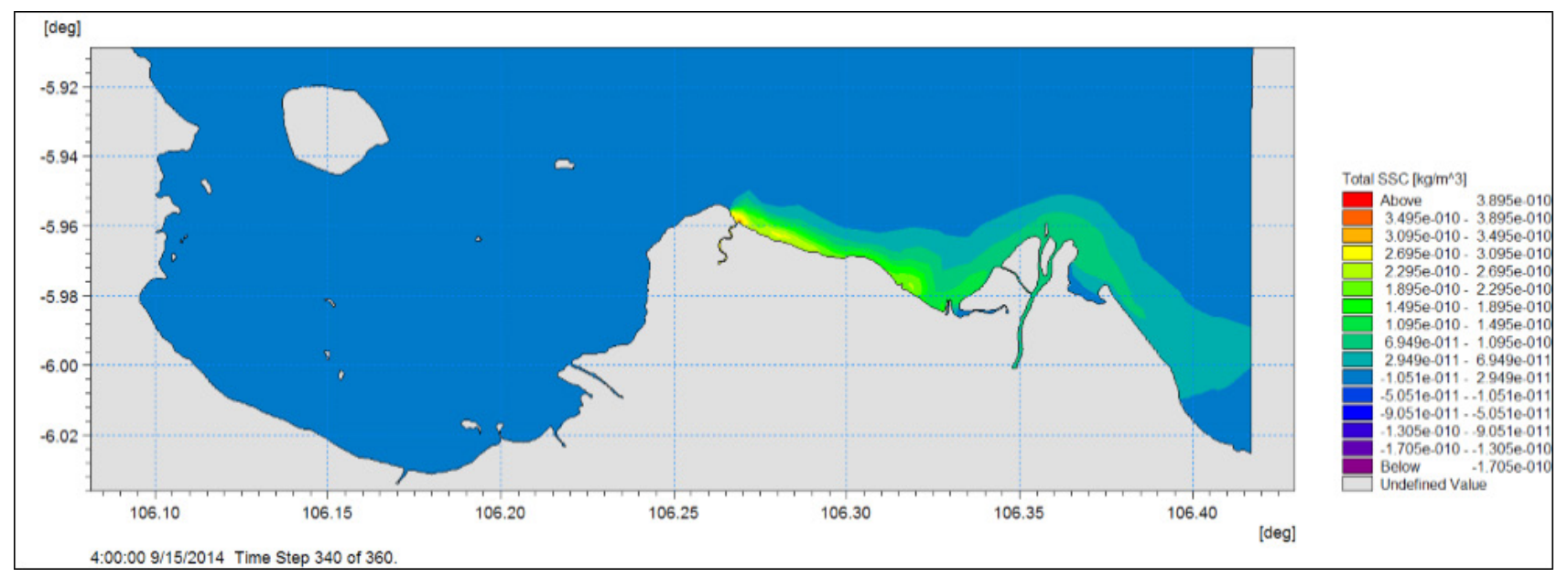

Gambar 16. Transpor sedimen layang saat kondisi pasang purnama pada domain utama model.

Figure 16. Suspended sediment transport during high spring tide at main modeling domain. Sumber: Hasil pengolahan data.

2004). Hal tersebut mengakibatkan penurunan suplai sedimen di daerah sungai Ciujung lama dan terjadi pengikisan sedimen oleh arus maupun gelombang laut.

Berdasarkan pemodelan transpor sedimen yang telah dibuat dapat diketahui bahwa sedimen secara dominan tertransportasikan ke arah timur di sekitar Sungai Ciujung Baru atau Desa Tengkurak. Hasil ini bukan berarti menunjukkan tidak ada sedimen yang tertransportasikan ke arah barat dan ke Teluk Banten. Hal ini lebih cenderung dikarenakan parameter pembangkit arus pada pemodelan transpor sedimen adalah pasang surut dan arus gelombang yang dibangkitkan oleh angin dari barat. Karena faktanya Teluk Banten juga selalu keruh dan ketebalan sedimennya bertambah (Hoekstra et al., 2003; Hoitink \& Hoekstra, 2003).

Selain itu berdasarkan pemodelan hidrodinamika dengan parameter angin juga menunjukkan adanya arus sejajar pantai yang bergerak menuju Teluk Banten akibat angin musim timur (Gambar 9 dan Gambar 10). Nilai kecepatan arus di titik observasi virtual di atas 0,1 $\mathrm{m} / \mathrm{s}$ juga menunjukkan adanya potensi abrasi di sekitar Tanjung Pontang pada musim barat dan musim timur (Dronkers, 2005). Namun sayangnya pada penelitian ini belum sempat dilakukan pemodelan transpor sedimen untuk musim timur untuk menunjukkan adanya transpor sedimen ke arah Teluk Banten.

Dengan demikian berdasarkan hasil penelitian ini dapat diketahui bahwa fenomena abrasi dan kekeruhan perairan di Tanjung Pontang memang nyata terjadi karena telah berhasil diidentifikasi oleh berbagai macam metode penelitian dan dibuktikan mekanisme transpor sedimennya pada penelitian ini. Dengan demikian usaha mitigasi diperlukan untuk mencegah abrasi di daerah tersebut supaya tidak terus mengikis pesisir utara Kabupaten Serang semakin berkurang luasannya dengan cara penanaman mangrove, (Akbar et al., 2017a; Akbar et al., 2017b; Thampanya et al., 2006; Hashim et al, 2010), pembangunan Alat Pemecah Ombak (APO) (Hartati et al., 2016), dan menggunakan metode eco-hybrid (Indriasari \& Akhwady, 2017).

\section{KESIMPULAN DAN SARAN}

Penelitian ini telah berhasil membuktikan dan menjelaskan adanya indikasi abrasi dan sedimentasi di sekitar Tanjung Pontang berdasarkan model numerik hidrodinamika dan transpor sedimen dengan perangkat lunak MIKE21.

Transpor sedimen di Sekitar Tanjung Pontang yang terkait dengan abrasi, sedimentasi dan kekeruhan sangat berkaitan dengan arus sejajar pantai (longshore current) di Tanjung Pontang. Parameter angin mempunyai pengaruh besar terhadap arus sejajar pantai tersebut. Angin musim barat mempunyai pengaruh yang lebih dominan dibandingkan angin musim timur. Pada saat musim barat arus sejajar pantai di Tanjung Pontang dominan bergerak ke arah timur, sedangkan pada saat musim timur sebagian arus sejajar pantai di Tanjung Pontang bergerak ke arah timur, dan sebagian bergerak ke selatan menuju Teluk Banten. Analisis perubahan bed level menunjukkan adanya penurunan bed level yang mengindikasikan abrasi di sekitar Tanjung Pontang dan sedimentasi di Sungai Ciujung Baru. Kekeruhan yang terjadi di sekitar Tanjung Pontang dan Teluk Banten disebabkan oleh karena adanya tingginya sedimen 
tersuspensi di Sungai Ciujung Lama dan terbawa oleh arus sejajar garis pantai di sekitar Tanjung Pontang.

Abrasi, sedimentasi dan kekeruhan di sekitar Tanjung Pontang merupakan permasalahan yang serius dan harus diatas. Dibutuhkan langkah mitigasi untuk mencegah abrasi di Tanjung Pontang semakin parah, misalkan dengan penanaman mangrove, breakwater, Alat Pemecah Ombak (APO), dan eco-hybrid.

\section{UCAPAN TERIMA KASIH}

Ucapan terima kasih disampaikan sebesar-besarnya kepada Pusat Penelitian dan Pengembangan Sumberdaya Laut dan Pesisir (P3SDLP), yang saat ini telah berubah nama menjadi Pusat Riset Kelautan, Badan Riset dan Sumberdaya Manusia, Kementerian Kelautan dan Perikanan, atas data-data yang digunakan pada penulisan artikel ini. Data yang dimaksud berasal dari kegiatan penelitian berjudul "Kajian Dampak Penambangan Pasir Laut Pantai Utara Banten untuk Reklamasi Teluk Jakarta Terhadap Sumber Daya Laut dan Pesisir" yang dibiayai oleh DIPA P3SDLP tahun 2014, sedangkan pemodelan dan pendalaman analisisnya dilakukan pada tahun 20162017. Lisensi MIKE21 adalah milik Pusat Pengkajian dan Perekayasaan Teknologi Kelautan yang telah bergabung dengan P3SDLP menjadi Pusat Riset Kelautan pada tahun 2017. Ucapan terima kasih juga diucapkan kepada Dr.-Ing. Widodo S. Pranowo dan Dr.-Ing. Semeidi Husrin atas diskusi, dan masukanmasukan yang telah diberikan pada saat penelitian ini dilakukan. Tidak lupa ucapan terima kasih kami ucapkan kepada reviewer yang telah menjadikan tulisan ini layak untuk diterbitkan.

\section{DAFTAR PUSTAKA}

Aldrian, E. (2001). Pembagian Iklim Indonesia Berdasarkan Pola Curah Hujan dengan Metoda "Double Correlation". Jurnal Sains \& Teknologi Modifikasi Cuaca, 2(1), 11-18.

Akbar, A. A., Sartohadi, J., Djohan, T. S., \& Ritohardoyo, S. (2017a). The Role of Breakwaters on The Rehabilitation of Coastal and Mangrove Forests in West Kalimantan, Indonesia. Ocean \& Coastal Management, 138(1), 50 - 59.

Akbar, A. A., Sartohadi, J., Djohan, T. S., \& Ritohardoyo, S. (2017b). Erosi Pantai, Ekosistem Hutan Bakau dan Adaptasi Masyarakat Terhadap Bencana Kerusakan Pantai di Negara Tropis. Jurnal Ilmu Lingkungan, 15 (1), 1-10.

Angkotasan, A. M., Nurjaya, I. W., \& Natih, N. M. (2012). Analisis Perubahan Garis Pantai Di Pantai Barat
Daya Pulau Ternate, Provinsi Maluku Utara. Jurnal Teknologi Perikanan dan Kelautan, 3(2), 11-22.

Bakosurtanal \& Dishidros TNI-AL. (1999). Teluk Banten Lembar LPI 1110-09 (1st Ed.), Skala 1:50.000. Peta Lingkungan Pantai Indonesia (LPI).

Dronkers, J. (2005). Dynamics of Coastal Systems, World Scientific.

Hartati, R., Pribadi, R., Astuti, R. W., Yesiana, R., H, \& Yuni, I. (2016). Kajian Pengamanan dan Perlindungan Pantai di Wilayah Pesisir Kecamatan Tugu dan Genuk, Kota Semarang. Jurnal Kelautan Tropis, 19(2), 95-100.

Hashim, R., Kamali, B., Tamin, N. M., \& Zakaria, R. (2010). An Integrated Approach to Coastal Rehabilitation: Mangrove Restoration in Sungai Haji Dorani, Malaysia. Estuarine. Coastal and Shelf Science, 86(1), 118 - 124

Husrin, S., \& Prihantono, J. (2014). Penambangan Pasir Laut. Bogor: IPB Press.

Husrin, S., Prihantono, J., \& Sofyan, H. (2014). Impacts of Marine Sand Mining Activities to the Community of Lontar Vilage, Serang - Banten. Bulletin of the Marine Geology, 29(2), 81-90.

Hoekstra (2003). Teluk Banten Research Programme: an Integrated Coastal Zone Management Study (1995 - 2001). Proceedings of SPIN Workshop, 59-70, Bandung.

Hoitink, A. J. F. \& Hoekstra, P. (2003). Hydrodynamic Control of The Supply of Reworked Terrigenous Sediment to Coral Reef in The Bay of Banten (NW Java, Indonesia). Estuarine Coastal and Shelf Science, $58,743-755$

Indriasari, V. Y., \& Akhwady, R. (2017). Rekayasa EcoHybrid untuk Restorasi Pantai Kedungu, Bali. Jurnal Ilmiah Teknik Sipil, 21(1).

Kusumawati, L. (2008). Penambangan Pasir Laut di Kabupaten Serang: Studi Kasus di Perairan Desa Lontar Kecamatan Tirtayasa. Tesis. Magister Perencanaan Kota dan Daerah: Universitas Gajah Mada.

Mustikasari, E., Dewi, L. C., Heriati, A., \& Pranowo, W. S. (2015). Pemodelan Pola Arus Barotropik Musiman 3 Dimensi (3D) untuk Mensimulasikan Fenomena Upwelling di Perairan Indonesia. Jurnal Segara, 11(1): 22-35.

NCDC-NOAA. NCDC Climate Data Online. Diakses 2 Mei 2017, dari https://www7.ncdc.noaa.gov/CDO/ dataproduct.

Novico, F., Astjario, P., \& Bachtiar, H. (2013). Kondisi Arus Pasang Surut dan Erosi-Sedimentasi di Sekitar Garis Pantai Depan PLTU Tarahan lampung menggunakan DELFT 3D Versi 3.28. Jurnal Geologi Kelautan, 11(1), 39-54.

Nugraha, R. B. A., Surbakti, H., Risandi, J., \& Mbay, L. O. N. (2014). Simulasi Pola Arus Laut Dua Dimensi di Perairan Sekitar Penida, Bali. Jurnal Kelautan Nasional, 9(1). 37-45.

Oktariani, D., Atmodjo, W., \& Widada, S. (2015). Transport Sedimen di Lokasi Perencanaan Pembangunan 
Pelabuhan Marunda, Jakarta Utara. Jurnal Oseanografi, 4(1), 325-332.

Ongkosongo, O. S. R., \& Wijonarko, S. (2014). Lingkungan Hidup Kabupaten Serang. Jakarta : Pusat Penelitian Oseanografi LIPI

P3SLDP. (2014). Kajian Dampak Penambangan Pasir Laut Pantai Utara Banten untuk Reklamasi Teluk Jakarta Terhadap Sumberdaya Laut dan Pesisir. Laporan Penelitian, P3SDLP. Jakarta: Kementerian Kelautan dan Perikanan.

Qomariyah, L., \& Yuwono. (2016). Analisa Hubungan antara Pasang Surut Air Laut dengan Sedimentasi yang Terbentuk. Jurnal Teknik ITS, 5(1), 1.

Rachmat, B., \& Purwanto, C. (2011). Morfologi Dasar Laut Kaitannya Dengan Proses Abrasi Pantai Di Perairan Pulau Marore, Sulawesi Utara. Jurnal Geologi Kelautan, 9(1), 29-44.

Rahmawan, G. A., Husrin, S., \& Prihantono, J. (2017). Analisa Perubahan Batimetri di Perairan Kabupaten Serang Akibat Penambangan Pasir Laut. Jurnal Ilmu dan Teknologi Kelautan Tropis, 9(1), 45-55.

Sufyan, A., Akhwady, R., Risandi, J., \& Syadiah, N. (2017). Analisa Hidro Oseanografi Pulau Liwungan untuk Studi Kelayakan Struktur Dermaga Apung. Jurnal Kelautan Nasional, 12(3). 127-139.

Syafik, A., Kunarso, \& Hariadi. (2013). Pengaruh Sebaran dan Gesekan Angin Terhadap Sebaran Suhu Permukaan Laut di Samudera Hindia (Wilayah Pengelolaan Perikanan Republik Indonesia 573). Jurnal Oseanografi, 2(3). 318-328.

Sugiyono.(2014). Metode Penelitian Pendidikan Pendekatan Kuantitatif, Kualitatif Dan R\&D. Bandung: Alfabeta.

Supiyati, Suwarsono, \& Setiawan, I. (2013). Pola Transport Sedimen Akibat Arus yang Dibangkitkan Gelombang Di Pelabuhan Pulau Baai Bengkulu. Prosiding Semirata, 91-97. Bandar Lampung: FMIPA Universitas Lampung.

Thampanya, U., Vermaat, J.E., Sinsakul, S., \& Panapitukkul, N., (2006). Coastal Erosion and Mangrove Progradation of Southern Thailand. Estuarine, Coastal and Shelf Science, 68, 74 - 85.

Triatmodjo, B. (2011). Perencanaan Bangunan Pantai. Cetakan Pertama. Yogyakarta : Beta Offset.

Umar. (2011). Kajian Pengaruh Gelombang Terhadap Kerusakan Pantai Matang Danau Kabupaten Sambas. Jurnal Teknik Sipil UNTAN, 11(1), 93-102.

Wibisono, M. (2005). Pengantar Ilmu Kelautan. Jakarta: PT Gramedia Widiasarana Indonesia.

Wyrtki, K. (1961). Physical Oceanography of the Southeast Asian Waters. Naga Report, Scripps Institution of Oceanography. La Jolla, California: The University of California

Wisha, U. J., Tanto, T. A., Pranowo, W. S., \& Husrin, S. (2018) Current Movement in Benoa Bay Water, Bali, Indonesia: Pattern of Tidal Current Changes Simulated for The Condition Before, During, and After Reclamation. Regional Studies in Marine Science, 18.177 - 187.
Wisha, U. J., Gemilang, W. A., Rahmawan, G. A., \& Kusumah, G. (2017). Pola Sebaran Sedimen Dasar Berdasarkan Karakteristik Morfologi dan HidroOseanografi Menggunakan Model Interpolasi dan Simulasi Numerik Di Perairan Utara Pulau Simeuluecut. Jurnal Kelautan, 10(1), 29-40.

Wisha, U. J., Husrin, S., \& Prihantono, J. (2015). Hidrodinamika Perairan Teluk Banten Pada Musim Peralihan (Agustus-September). Ilmu Kelautan, 20(2), 105.

Yudhicara \& Yosi, M. (2011). Proses Abrasi di Kawasan Pantai Lombong, Majene, Sulawesi Barat. Jurnal Geologi Kelautan, 9(3), 159-174.

JURNAL KELAUTAN NASIONAL, Vol. 13, No 2, Agustus 2018, Hal. 75-88 